Syntax Idea: p-ISSN: 2684-6853 e-ISSN: 2684-883X

Vol. 3, No. 2, Februari 2021

\title{
ANALISIS PENGARUH KUALITAS PRODUK TERHADAP KEPUASAN PELANGGAN PADA COUNTER HANDHPHONE "VENUS CELLULAR" TANGERANG
}

\author{
Risfa Dewi, Andri Suseno dan Mertha Widiyastuti Adhi \\ Universitas Budi Luhur Jakarta, Indonesia \\ Email: Risfadewi@yahoo.com, Andri.suseno@gmail.com dan merthaubl@gmail.com
}

\section{Abstract}

The purpose of this study was to analyze the Effect of Product Quality on Customer Satisfaction on Handhphone Counter "Venus Cellular" Tangerang. This type of research used in writing is descriptive research, using qualitative approach. Descriptive research is a form of research aimed at describing existing phenomena, both natural phenomena and man-made phenomena. The phenomenon can be the form, activity, characteristics, changes, relationships, similarities, and differences between phenomena with each other. The implications of this make a quality brand will create an image of the product itself in the mind of the customer and make the basic motivation for customers in choosing a product. A product is said to have good quality if it has a positive impact on the company which includes increasing sales and improving the company's image in the eyes of the public, as well as increasing public knowledge of the use of the product, thus the quality of a product will have an effect in customer purchasing decisions. This is also done by venus cellular tangerang customers in making product purchase decisions by paying attention and considering the brand image and product quality owned by venus cellular Tangerang. The implications of this make a quality brand will create an image of the product itself in the mind of the customer and make the basic motivation for customers in choosing a product. A product is said to have good quality if it has a positive impact on the company which includes increasing sales and improving the company's image in the eyes of the public, as well as increasing public knowledge of the use of the product, thus the quality of a product will have an effect in customer purchasing decisions.

Keywords: product quality; customer satisfaction; business

\section{Abstrak}

Tujuan penelitian ini untuk menganalisis Pengaruh Kualitas Produk Terhadap Kepuasan Pelanggan Pada Counter Handhphone "Venus Cellular" Tangerang. Jenis penelitian yang digunakan dalam penulisan ini merupakan penelitian deskriptif, dengan menggunakan pendekatan kualitatif. Penelitian deskriptif adalah suatu bentuk penelitian yang ditujukan untuk mendeskripsikan fenomena-fenomena yang ada, baik fenomena alamiah maupun fenomena buatan manusia. Fenomena itu bisa berupa bentuk, aktivitas, karakteristik, perubahan, hubungan, kesamaan, dan perbedaan antara fenomena yang satu dengan fenomena lainnya. Implikasi dari hal tersebut menjadikan merek yang berkualitas akan menciptakan citra dari produk itu sendiri di benak pikiran pelanggan dan menjadikan motivasi dasar bagi pelanggan 
dalam memilih suatu produk. Suatu produk dikatakan memiliki kualitas yang baik apabila mempunyai dampak yang positif terhadap perusahaan yang meliputi peningkatan penjualan dan peningkatan pencitraan perusahaan dimata masyarakat, serta peningkatan pengetahuan masyarakat akan penggunaan produk tersebut, dengan demikian kualitas suatu produk akan berpengaruh dalam keputusan pembelian pelanggan. Hal ini pula yang dilakukan oleh pelanggan venus cellular tangerang dalam melakukan keputusan pembelian produk dengan memperhatikan dan pempertimbangkan citra merek dan kualitas produk yang dimiliki oleh venus cellular Tangerang. Implikasi dari hal tersebut menjadikan merek yang berkualitas akan menciptakan citra dari produk itu sendiri di benak pikiran pelanggan dan menjadikan motivasi dasar bagi pelanggan dalam memilih suatu produk. Suatu produk dikatakan memiliki kualitas yang baik apabila mempunyai dampak yang positif terhadap perusahaan yang meliputi peningkatan penjualan dan peningkatan pencitraan perusahaan dimata masyarakat, serta peningkatan pengetahuan masyarakat akan penggunaan produk tersebut, dengan demikian kualitas suatu produk akan berpengaruh dalam keputusan pembelian pelanggan.

Kata kunci: kualitas produk; kepuasan pelanggan; bisnis

\section{Pendahuluan}

Saat ini perkembangan dunia bisnis telah mengalami banyak kemajuan yang cukup pesat sehingga mendorong persaingan antar perusahaan semakin meningkat (Utami, 2012). Persaingan tersebut muncul karena adanya perubahan yang terjadi pada pola hidup dan konsumsi masyarakat yang selalu ingin memenuhi kebutuhan hidupnya baik kebutuhan biologis maupun psikologis. Perusahaan harus dapat memahami kebutuhan dan keinginan pelanggan yang terus meningkat. Sebelum menciptakan suatu produk, perusahaan harus dapat memperkirakan seberapa banyak pelanggan yangbenarbenar ingin dan mampu membeli produknya (Danial, 2018).

Perusahaan yang bergerak di bidang produksi maupun di bidang jasa pada dasarnya adalah pencapaian tujuan yang telah diterapkan, ada yang berorientasi pada keuntungan maksimal dan ada yang tidak berorientasi pada keuntungan maksimal misalnya dalam bentuk sosial, namun untuk menjaga kelangsungan hidup perusahaan keuntungan perusahaan diharapkan tetap ada agar perusahaan dapat menjalankan aktivitasnya dalam mencapai tujuan, baik tujuan jangka pendek maupun tujuan jangka panjang. Konsep produk yang berkaitan dengan reputasi produk sebagai persepsi dari kualitas barang/jasa yang berhubungan dengan nama produknya (Natalia, 2010). Kualitas produk adalah segala sesuatu yang memiliki nilai di pasar sasaran target market dimana kemampuannya memberikan manfaat dan kepuasan, termasuk hal ini aalah benda, jasa, organisasi, tempat, orang dan ide (Fatihudin \& Firmansyah, 2019).

Dalam hal ini perusahaan memusatkan perhatian mereka pada usaha untuk menghasilkan produk yang unggul dan terus menyempurnakan. Produk yang berkualitas tinggi merupakan salah satu kunci sukses perusahaan. Di era globalisasi, persaingan bukan sesuatu yang harus dihindari, namun persaingan global perlu dipersiapkan. Berbicara persaingan tentu membicarakan keadaan tantangan yang datang dari luar 
perusahaan bahkan lebih luas lagi jangkauannya (Saridawati, 2018). Memperbaiki kualitas produk ataupun jasa merupakan tantangan yang penting bagi perusahaan bersaing di pasar global (Rahmidani, 2015). Perbaikan kualitas produk akan mengurangi biaya dan meningkatkan keunggulan bersaing, bahkan lebih jauh lagi, kualitas produk yang tinggi menciptakan keunggulan bersaing yang bertahan lama (Kotler \& Armstrong, 2014).

\section{Metode Penelitian}

1. Jenis Penelitian

Jenis penelitian yang digunakan dalam penulisan ini merupakan penelitian deskriptif, dengan menggunakan pendekatan kualitatif (Sugiyono, 2010). Penelitian deskriptif adalah suatu bentuk penelitian yang ditujukan untuk mendeskripsikan fenomena-fenomena yang ada, baik fenomena alamiah maupun fenomena buatan manusia. Fenomena itu bisa berupa bentuk, aktivitas, karakteristik, perubahan, hubungan, kesamaan, dan perbedaan antara fenomena yang satu dengan fenomena lainnya (Sukmadinata, 2006).

2. Sample dan Populasi

Populasi pada penelitian ini adalah counter handhphone "venus cellular" tangerang, dimana peneliti meneliti sampel dari keseluruhan populasi yang ada (sample jenuh).

3. Prosedur Pengambilan \& Pengumpulan Data

Adapun teknik pengumpulan data yang digunakan peneliti dalam penelitian sebagai berikut:

a. Observasi

Teknik pengumpulan observasi yang digunakan adalah participant observation, yaitu dimana peneliti terlibat secara langsung dalam kegiatan sehari-hari pada counter handhphone "venus cellular" tangerang sebagai sumber data.

b. Wawancara

Teknik pengumpulan dengan cara wawancara yang digunakan adalah wawancara tidak terstruktur, yaitu peneliti hanya memuat poin-poin penting pada kasus counter handhphone "venus cellular" tangerang dari responden.

\section{Hasil dan Pembahasan}

\section{Hasil}

Implikasi dari hal tersebut menjadikan merek yang berkualitas akan menciptakan citra dari produk itu sendiri di benak pikiran pelanggan dan menjadikan motivasi dasar bagi pelanggan dalam memilih suatu produk (Susanto \& Wijarnako, 2004). Suatu produk dikatakan memiliki kualitas yang baik apabila mempunyai dampak yang positif terhadap perusahaan yang meliputi peningkatan penjualan dan peningkatan pencitraan perusahaan dimata masyarakat, serta peningkatan pengetahuan masyarakat akan penggunaan produk tersebut, dengan 
demikian kualitas suatu produk akan berpengaruh dalam keputusan pembelian pelanggan. Hal ini pula yang dilakukan oleh pelanggan venus cellular tangerang dalam melakukan keputusan pembelian produk dengan memperhatikan dan pempertimbangkan citra merek dan kualitas produk yang dimiliki oleh venus cellular tangerang (Amilia, 2017).

\section{Pembahasan}

a. Penerapan Kualitas Produk Dalam Meningkatkan Kepuasan Pelanggan Venus Cellular Tangerang

Selama ini venus cellular tangerang sudah memberikan kualitas produk dengan sesuai aturan yang berlaku di perusahaan Kualitas produk merupakan segala sesuatu yang dapat memenuhi kebutuhan yang ditawarkan perusahaan untuk diperhatikan diminta digunakan oleh pelanggan. Kualitas dapat dikategorikan sebagai suatu senjata yang strategis untuk berkompetisi dengan para pesaing. Karena peran kualitas produk sangat menentukan keinginan pelanggan tersebut sehingga dengan kualitas produk akan tercapai suatu kepuasan tersendiri bagi pelanggan hal ini dilakukan untuk meminimalisir kerugian perusahaan serta kepuasan pelanggan karena barang atau produk yang mereka terima dalam keadaan baik dan tidak rusak (Bailia, Soegoto, \& Loindong, 2014).

b. Penerapan Kualitas Produk Dalam Meningkatkan Kepuasan Pelanggan Venus Cellular Tangerang Seharusnya

Dalam meningkatkan kepuasan pelanggan kualitas produk yang diberikan suatu produk juga bisa menjadi alasan pelanggan untuk loyal terhadap produk tersebut. Produk yang dijual menawarkan kualitas yang baik maka pelanggan akan membelinya, setelah itu jika pelanggan merasa puas akan membeli ulang produk tersebut dan akan menjadi pelanggan yang loyal. Agar dapat bersaing, bertahan hidup dan berkembang, perusahaan dituntut untuk mampu memberikan kualitas produk berkualitas yangdapat memenuhi kebutuhan dan keinginan pelanggan. Produk dan jasa yang tidak memenuhi kualitas dengan sangat mudah ditinggalkan danakhirnya pelanggan beralih ke yang lain. Untuk mengantisipasi hal tersebut tentunya akan mengutamakan perluasan produk dan kualitas produk yang berorientasi pada kualitas produk yang mengutamakan keputusan pembelian (Rangkuti, 2006).

Suatu produk dikatakan memiliki kualitas yang baik apabila mempunyai dampak yang positif terhadap perusahaan yang meliputi peningkatan penjualan dan peningkatan pencitraan perusahaan dimata masyarakat, serta peningkatan pengetahuan masyarakat akan penggunaan produk tersebut, dengan demikian kualitas suatu produk akan berpengaruh dalam keputusan pembelian pelanggan (Bachriansyah \& Ferdinand, 2011).

Pelanggan juga akan mempertimbangkan baik buruknya kualitas dari barang yang akan digunakannya tersebut. Pelanggan akan lebih memilih produk 
yang tahan lama mudah digunakan serta memiliki pencitraan yang baik (Rachman \& Santoso, 2014). Implikasi dari hal tersebut menjadikan merek yang berkualitas akan menciptakan citra dari produk itu sendiri di benak pikiran pelanggan dan menjadikan motivasi dasar bagi pelanggan dalam memilih suatu produk. Hal ini pula yang dilakukan oleh pelanggan venus cellular tangerang dalam melakukan keputusan pembelian produk dengan memperhatikan dan pempertimbangkan citra merek dan kualitas produk yang dimiliki oleh venus cellular tangerang.

\section{Kesimpulan}

Implikasi dari hal tersebut menjadikan merek yang berkualitas akan menciptakan citra dari produk itu sendiri di benak pikiran pelanggan dan menjadikan motivasi dasar bagi pelanggan dalam memilih suatu produk. Suatu produk dikatakan memiliki kualitas yang baik apabila mempunyai dampak yang positif terhadap perusahaan yang meliputi peningkatan penjualan dan peningkatan pencitraan perusahaan dimata masyarakat, serta peningkatan pengetahuan masyarakat akan penggunaan produk tersebut, dengan demikian kualitas suatu produk akan berpengaruh dalam keputusan pembelian pelanggan. Hal ini pula yang dilakukan oleh pelanggan venus cellular tangerang dalam melakukan keputusan pembelian produk dengan memperhatikan dan pempertimbangkan citra merek dan kualitas produk yang dimiliki oleh venus cellular tangerang.

\section{BIBLIOGRAFI}

Amilia, Suri. (2017). Pengaruh citra merek, harga, dan kualitas produk terhadap keputusan pembelian handphone merek xiaomi di kota langsa. Jurnal Manajemen Dan Keuangan, 6(1), 660-669.

Bachriansyah, Rizky Amalina, \& Ferdinand, Augusty Tae. (2011). “Analisis Pengaruh Kualitas Produk, Daya Tarik Iklan, dan Persepsi Harga Terhadap Minat Beli Konsumen Pada Produk Ponsel Nokia (Studi Kasus Pada Masyarakat di Kota Semarang). Universitas Diponegoro.

Bailia, Jefry F. T., Soegoto, Agus Supandi, \& Loindong, Sjendry Serulo R. (2014). Pengaruh kualitas produk, harga dan lokasi terhadap kepuasan konsumen pada warung-warung makan lamongan di kota Manado. Jurnal EMBA: Jurnal Riset Ekonomi, Manajemen, Bisnis Dan Akuntansi, 2(3).

Danial, Muhamad Muhsiy. (2018). Pengaruh Motivasi Terhadap Keputusan Pembelian: Studi Kasus Pada hendphone nokia di Jakarta.

Fatihudin, Didin, \& Firmansyah, Anang. (2019). Pemasaran Jasa:(Strategi, Mengukur Kepuasan Dan Loyalitas Pelanggan). Deepublish. 
Risfa Dewi, Andri Suseno dan Mertha Widiyastuti Adhi

Kotler, Philip, \& Armstrong, Gary. (2014). Principle Of Marketing, vol. New Jersey: Pearson Prentice Hall.

Natalia, Selly. (2010). Pengaruh citra merek, kualitas produk dan kualitas pelayanan terhadap loyalitas pelanggan melalui kepuasan pelanggan pada marcelio speed shop. Manajemen Bisnis.

Rachman, Bayu Januar, \& Santoso, Suryono Budi. (2014). Analisis Pengaruh Desain Produk dan Promosi Terhadap Kemantapan Keputusan Pembelian yang Dimediasi Oleh Citra Merek (Studi pada Customer Distro Jolly Roger Semarang). Fakultas Ekonomika dan Bisnis.

Rahmidani, Rose. (2015). Penggunaan e-commerce dalam bisnis sebagai sumber keunggulan bersaing perusahaan. Prosiding Seminar Nasional Ekonomi Manajemen Dan Akutansi (SNEMA), 345-352.

Rangkuti, Freddy. (2006). Teknik mengukur dan strategi meningkatkan kepuasan pelanggan. Jakarta: Gramedia Pustaka Utama, 109-113.

Saridawati, Saridawati. (2018). Pengelolaan Dan Pengembangan Sumber Daya Manusia Pada Pt. Atmoni Shamasta Prezki. Syntax Literate; Jurnal Ilmiah Indonesia, 3(9), $107-122$.

Sugiyono. (2010). Metode Penelitian Kuantitatif Kualitatif dan $R \&$ D. Bandung: Alfabeta.

Sukmadinata. (2006). Metode Penelitian Kualitatif. Bandung: Graha Aksara.

Susanto, A. B., \& Wijarnako, Himawan. (2004). Power branding: Membangun merek unggul dan organisasi pendukungnya. Mizan Pustaka.

Utami, Setyaningsih Sri. (2012). Pengaruh Teknologi Informasi Dalam Perkembangan Bisnis. Jurnal Akuntansi Dan Sistem Teknologi Informasi, 8(1). 